\title{
Kecerdasan intelektual dan prestasi belajar siswa kelas XI MIPA SMA Negeri 8 Yogyakarta
}

\author{
Kurniawatia,1* ${ }^{*}$, Yuzarion Zubirb,2 \\ a,bMagister Psikologi, Universitas Ahmad Dahlan, Yogyakarta \\ *1kurniawati2007044015@webmail.uad..ac.id; 2yuzarionzubir11@gmail.com \\ *Correspondent Author
}

K A T A KU N C I
kecerdasan;
kecerdasan intelektual;
prestasi belajar
prestasi belajar

\section{KEYWORDS}

intelligence; intellectual intelligence; student achievement

\section{ABSTRAK}

Belajar merupakan proses internalisasi ilmu pengetahuan dan pengalaman individu dengan hasil pada perubahan perilaku atau ketrampilan. Salah satu tugas seorang pendidik adalah melakukan penilaian terhadap siswa untuk mengukur tingkat keberhasilan proses pembelajaran. Penilaian tersebut dapat berupa angka, huruf atau kata-kata yang lebih umum disebut dengan prestasi belajar. Banyak penelitian menunjukkan bahwa kecerdasan intelektual bukanlah menjadi prediktor utama prestasi belajar, namun keberadaannya masih memiliki pengaruh. Faktor kecerdasan intelektual seseorang masih diyakini mempunyai andil dalam mempengaruhi hasil belajar. Pada penelitian ini, tujuan penelitian adalah ingin melakukan pengujian secara empiris terkait dengan pengaruh kecerdasan intelektual terhadap prestasi belajar siswa. Metode pada penelitian ini menggunakan metode kuantitatif korelasional. Partisipan pada penelitian ini adalah 40 siswa kelas XI dengan peminatan MIPA yang telah diperoleh dengan teknik sampel acak. Analisis data dengan metode regresi linear sederhana menunjukkan bahwa kecerdasan intelektual berpengaruh secara positif dan signifikan pada capaian prestasi belajar siswa. Berdasarkan hasil penelitian menunjukan nilai koefisien determinasi $\left(\mathrm{R}^{2}\right)$, kecerdasan intelektual diprediksikan berkontribusi sebesar 29,4\% terhadap prestasi belajar siswa. Oleh karena itu penelitian ini menyimpulkan bahwa kecerdasan intelektual memiliki hubungan yang signifikan terhadap prestasi belajar siswa-siswi kelas XI peminatan MIPA SMA Negeri 8 Yogyakarta.

\section{Intellectual intelligence and student achievement class XI MIPA SMA Negeri 8 Yogyakarta}

Learning is a process of internalizing knowledge and individual experiences with the result in changes in behavior or skills. One of the duties of an educator is to conduct an assessment of students to measure the level of success of the learning process. The assessment can be in the form of numbers, letters or words which are more commonly referred to as learning achievements. Many studies show that intellectual intelligence is not the main predictor of learning achievement, but its existence still has an influence. The intellectual intelligence factor of a person is still believed to have a role in influencing learning outcomes. In this study, the research objective is to conduct empirical testing related to the influence of intellectual intelligence on student achievement. The method in this study uses correlational quantitative methods. The participants in this study were 
40 students of class XI with a specialization in Mathematics and Natural Sciences that had been obtained using a random sample technique. Data analysis using simple linear regression method shows that intellectual intelligence has a positive and significant effect on student achievement. Based on the results of the study showed the value of the coefficient of determination (R2), intellectual intelligence is predicted to contribute $29.4 \%$ to student achievement. Therefore, this study concludes that intellectual intelligence has a significant relationship to the learning achievement of class XI students specializing in Mathematics and Natural Sciences at SMA Negeri 8 Yogyakarta.

This is an open-access article under the CC-BY-SA license.

\section{Pendahuluan}

Pendidikan merupakan aktifitas yang diselenggarakan untuk meningkatkan kualitas hidup manusia. Sistem pendidikan dibangun untuk mengatur proses pembelajaran yang di dalamnya akan dijabarkan mulai dari input, proses dan luaran (Amaliyah, 2017). Sesuai dengan yang tertuang di dalam Undang-Undang No.20 tahun 2003 tentang Sistem Pendidikan Nasional dijelaskan bahwa setiap warga negara berhak mendapatkan pendidikan yang layak (Depdikbud, 2003). Sementara belajar merupakan proses penting dari penyelenggaraan pendidikan yang akan melibatkan interaksi antara pendidik dan pembelajar (Farida, 2016).

Belajar merupakan proses yang dialami seseorang dan membawa suatu perubahan pada cara seseorang saat memberikan respon terhadap informasi yang diterimanya (Fitriana, Imron, \& Arif, 2017). Wurdani dan Esti (dalam Nurhayani \& Syahrizal, 2016) menjelaskan belajar sebagai anteseden dari perubahan tingkah laku seseorang. Berikutnya, hasil dari belajar adalah perubahan perilaku individu, artinya representasi dari belajar akan tercermin melalui prestasi yang diraih. Seseorang dinilai telah melakukan belajar jika respon dari kegiatan belajar adalah ada perubahan pada perilakunya. Selanjutnya hasil pembelajaran yang dapat diukur oleh pendidik sebagai ukuran tingkat capaiaan adalah prestasi belajar. Secara umum penilaian hasil belajar ini dilakukan oleh para pendidik untuk mengetahui keberhasilan capaian pendidikan berdasarkan ukuran yang sudah ditetapkan (Nurhayati \& Syahrizal, 2016). Menurut Imas (2014), proses belajar merupakan komponen utama dalam proses pemberian ilmu, pembentukan ketrampilan dan diperluas lagi mencakup usaha yang dilakukan untuk dapat mewujudkan keinginan, kebutuhan, serta kemampuan individu. Hal ini menunjukkan bahwa belajar merupakan hal yang pokok, dan keberhasilan capaian dari pembelajaran dipengaruhi oleh proses belajar yang dilakukan siswa.

Nurbaeti, Nuryanti, dan Pursitasari (2015) menjelaskan bahwa hasil belajar dipengaruhi kemampuan kognitif seseorang. Para ahli meyakini bahwa seseorang yang pandai dan sukses adalah yang mempunyai kecerdasan intelektual tinggi, sehingga mampu menyelesaikan masalah dengan logis dan akademis (Rahardjo, 2010). Menurut Kuncel, dkk (dalam Pratama \& Corebima, 2015) kecerdasan merupakan faktor yang mendasar untuk memprediksikan capaian kesuksesan siswa dimasa yang akan datang. Kecerdasan dalam diri individu merupakan suatu kemampuan untuk menyerap informasi atau pengetahuan baru yang kemudian menjadikannya sebagai dasar untuk dapat mengolah dan menyelesaikan suatu masalah (Pratama \& Corebima, 2015).

Prestasi belajar menurut KBBI (dalam Nurhayati \& Syahrizal, 2016) merupakan suatu capaian individu dari hasil aktifititas. Prestasi belajar merupakan sesuatu yang diterima oleh seorang pembelajar melalui proses yang dituangkan dalam bentuk kata, huruf dan kata-kata (Arikunto, 2006). Pretasi belajar merupakan komponen penting dalam sistem pendidikan 
sebagai indikator keberhasilan suatu proses pembelajaran dijalankan. Begitupula, bahwa prestasi belajar bagi peserta didik merupakan hal yang penting, karena prestasi ini merupakan salah satu gambaran tingkat keberhasilan dari suatu kegiatan yang diselenggarakan selama mengikuti proses pembelajaran yang dilakukan oleh pendidik (Zuffianò, dkk, 2013). Sesuai dengan yang disampaikan Sulastyaningrum, Martono, dan Wahyono (2019) bahwa keberhasilan suatu proses pembelajaran ditunjukkan oleh tingkat prestasi belajar yang dicapai oleh pembelajar. Jika prestasi belajar masih rendah dapat diartikan masih terdapat terdapat permasalahan dalam proses pembelajaran yang berasal dari sistemnya ataupun dalam diri peserta didik.

Prestasi belajar dapat diketahui setelah seorang siswa mengikuti proses evaluasi. Hasil dari evaluasi akan menunjukkan tinggi rendahnya prestasi belajar seorang siswa. Indikator belajar menurut Sudjana (2010) meliputi beberapa kategori antara lain ketrampilan dan kebiasaan, pengetahuan dan ketrampilan, sikap dan cita-cita. Indikator yang banyak dipergunakan dikategorikan menjadi tiga yaitu kognitif, afektif dan psikomotorik. Kategori kognitif yang berkaitan dengan hasil belajar meliputi enam komponen yang meliputi: pengetahuan, pemahaman, aplikasi, analisis, sintesis dan evaluasi (Bloom, dalam Sujana 2002). Pengetahuan dan pemahaman disebut kognitif tingkat rendah, sedangkan empat komponen lainnya termasuk kognitif tingkat tinggi.

Berbicara tentang prestasi belajar, salah satu faktor yang mempengaruhi prestasi belajar adalah kecerdasan. Kecerdasan (inteligensi) secara etimologi berasal dari Bahasa Inggris, "intelligence' yang berasal dari Bahasa Latin "intellectus dan intelegentia atau intellegere", yang artinya memahami. Teori mengenai kecerdasan ini pertama kalinya diungkapkan oleh Spearman dan Wynn Jones pada tahun 1951 (dalam Suryabrata, 2006). Pengertian kecerdasan menurut beberapa pakar Ilmu Psikologi merujuk pada proses penyesuaian diri individu secara mental menghadapi situasi dan kondisi yang baru (Claparedese \& Stern, dalam Davidoff, 2000). Menurut Thorndike (dalam Parauba, 2014), kecerdasan merupakan kemampuan seseorang dalam memberikan respon yang tepat terhadap rangsangan atau stimulus. Berikutnya, Wechsler (dalam Azwar, 2002) menjelaskan kecerdasan sebagai kemampuan berpikir dan melakukan tindakan secara terarah, teratur serta mampu mengolah informasi dan menguasai lingkungan secara efektif. Begitupula Binet, Ziedner, dan Zenderland (dalam Pratama \& Corebima, 2015) mengungkapkan bahwa kecerdasan berhubungan erat dengan kemampuan kognitif individu yang meliputi kemampuan berpikir, mengingat, membaca, dan memecahkan permasalahan.

Sejauh ini masyarakat memahami intelektual sebagai gambaran kecerdasan, kepintaran dan kemampuan memecahkan masalah (Alfionita, Jamaludin, \& Fitrayadi, 2019). Kecerdasan intelektual merupakan kemampuan menganalisa, menyelesaikan masalah logika dan rasional. Kecerdasan ini merupakan kemampuan untuk menerima, menyimpan serta mengelola suatu informasi menjadi fakta atau tindakan nyata (Widodo, dalam Bestari dan Marhalinda, 2017). Menurut Dinger dan Dickhäuser (2013) bahwa intelektual merupakan kemampuan menafsirkan situasi terhadap capaian yang akan diraih. Sebaliknya seseorang dengan tingkat kecerdasan intelektual yang rendah akan mengalami kesulitan dalam menyerap informasi saat belajar, lambat berpikir dan hasil belajarnyanya pun akan rendah (Rosa, 2018).

Binet (dalam Nurhayati \& Syahrizal, 2016) mengemukakan bahwa interpretasi dari kecerdasan intelektual adalah memahami, berpendapat, mengontrol dan mengkritik. Sementara Purwanto (dalam Rosa, 2018) menjelaskan karakteristik seseorang dikatakan cerdas apabila melakukan hal-hal berikut: (1). mampu menghadapi dan menyelesaikan masalah baru yang dihadapi, (2). mampu mencapai tujuan yang ditetapkan dengan cepat dengan perhitungan hemat waktu dan tenaga yang digunakan, (3) mampu menyelesaikan suatu masalah yang memiliki tingkat kesulitan yang tidak sesuai dengan perkembangan 
usianya, (4) mampu menjelaskan informasi dan dapat diterima oleh masyarakat, (5) memiliki kemampuan abstraksi dan (5) memiliki kemampuan untuk fokus dalam satu masalah untuk diselesaikan. Selanjutnya menurut Carter (2009), terdapat empat komponen untuk mengukur kecerdasan intelektual: (1) kemampuan verbal merupakan kemampuan dalam bidang bahasa, (2) kemampuan numerik merupakan kemampuan dalam hal perhitungan dan angka, (3) kemampuan spasial adalah kemampuan dalam bidang abstrak dan (4) kemampuan logis merupakan kemampuan dalam berpikir secara logis.

Kerangka berpikir penelitian ini berpijak pada asumsi yang didasarkan bahwa terdapat hubungan positif dan signifikan antara kecerdasan intelektual dan capaian prestasi belajar siswa. Kecerdasan intelektual merupakan kemampuan berpikir seseorang yang dapat membantu manusia dalam proses penyesuaian diri dengan lingkungan, menghadapi dan menyelesaikan masalah-masalah yang dihadapinya. Sesuai dengan yang diungkapkan Handriani dan Subhan (2020) bahwa kecerdasan intelektual membantu seseorang memecahkan persoalan yang dihadapi secara logis dan menggunakan konsep abstrak yang dipahaminya. Bagi seorang pembelajar, kecerdasan intelektual ini masih diyakini turut menentukan kemampuan peserta didik dalam memahami dan mengolah informasi selama proses belajar. Begitupula, bahwa kecerdasan intelektual juga mampu membantu guru atau pengajar untuk memetakan kondisi peseta didik, dalam hal ini apakah peserta didik mampu mengikuti proses pembelajaran yang diselenggarakan, serta memprediksikan keberhasilan atau kegagalan peserta didik dalam mengikuti proses pembelajaran.

Hasil penelitian Puspatandjali, Mallo, dan Hadjar (2015) menunjukan adanya pengaruh kecerdasan intelektual (IQ) terhadap prestasi belajar matematika sebesar 27,4\%, penelitian ini juga menjelaskan bahwa kecerdasan intelektual (IQ) memiliki pengaruh yang lebih tinggi dibandingkan dengan kecerdasan emosional (EQ terhadap prestasi belajar. Sejauh ini telah banyak dilakukan penelitian yang mengkaji untuk menyediki peran kecerdasan intelektual dalam pencapaian prestasi belajar siswa. Semakin banyak temuan yang mengemukakan bahwa kecerdasan intelektual bukanlah satu-satunya penentu kesuksesan seseorang. Meski tidak menjadi penentu namun berdasarkan banyak penelitian mempunyai peran dalam menentukan prestasi seseorang. Pembahasan mengenai kecerdasan intelektual dan prestasi akademik masih menjadi perdebatan yang panjang (Pratama dan Corebima, 2015). Oleh karena itu, penelitian ini dimaksudkan untuk menguji pengaruh kecerdasan intelektual terhadap capaian hasil belajar siswa dan seberapa besar peranan kecerdasan intelektual ini berkontribusi dalam prestasi seorang pelajar.

\section{Metode}

Penelitian ini menggunakan metode kuantitatif korelasional untuk menyelidiki hubungan kecerdasan intelektual dan prestasi belajar. Partisipan penelitian ini adalah 40 siswa kelas XI peminat MIPA di SMAN 8 Yogayakarta yang dipilih dengan teknik random sampling. Teknik analisis data yang digunakan untuk menguji hubungan variabel kecerdasan intelektual dan prestasi belajar adalah menggunakan uji regresi sederhana dengan bantuan perangkat lunak SPSS versi 22. Teknik ini menguji signifikasi pengaruh kecerdasan intelektual terhadap prestasi belajar siswa. Koefisien determinasi $\left(\mathrm{R}^{2}\right)$ pada intinya mengukur seberapa jauh kemampuan model dalam memvariasi variabel tergantung. Sedangkan uji statistik $t$ untuk menunjukkan seberapa jauh pengaruh variabel bebas secara individual (kecerdasan intelektual) dalam menerangkan variasi variabel tergantung (prestasi belajar).

\section{Hasil}

Berdasarkan data yang diperoleh dari pengambilan pengambilan data pada tabel 1 , menunjukan bahwa koefisien regresi dari kecerdasan intelektual dengan prestasi belajar adalah sebesar $\mathrm{R}=0,544, \mathrm{~F}$ sebesar=15,943 dengan $\mathrm{p}=0,000(\mathrm{p}<0,001)$. Hasil penelitian 
menunjukan bahwa ada pengaruh yang signifikan dari kecerdasan intelektualterhadap prestasi belajar, hipotesa diterima. Hasil analisis juga menunjukan nilai $\mathrm{R}^{2}$ sebesar 0,296, yang menjelaskan sebagai besarnya pengaruh kecerdasan intelektual terhadap prestasi belajar yaitu $29,6 \%$.

Tabel 1.

Uji Persamaan Regresi Kecerdasan Intelektual dan Prestasi Belajar

\begin{tabular}{clllll}
\hline Model & $\boldsymbol{R}$ & $\boldsymbol{F}$ & $\boldsymbol{R}$ Square & $\begin{array}{l}\text { Adjusted } \boldsymbol{R} \\
\text { Square }\end{array}$ & $\begin{array}{l}\text { Std. Error of } \\
\text { the Estimate }\end{array}$ \\
\hline 1 &, $544^{\mathrm{a}}$ & 15,943 &, 296 &, 277 & 4,080 \\
\hline
\end{tabular}

Persamaan regresi berdasarkan analisis data menunjukan $y=9,314+0,914 \mathrm{x}$ (pada tabel 2). Koefisien regresi x sebesar 0,914 mengartikan bahwa jika faktor kecerdasan intelektual (x) meningkat sebesar 1 satuan skor dari kondisi sebelumnya maka prestasi belajar siswa (y) akan meningkat sebesar 0,914 dari kondisi sebelumnya.

Tabel 2.

Koefisien Persamaan Regresi Kecerdasan Intelektual dan Prestasi Belajar

\begin{tabular}{lllllll}
\hline & & $\begin{array}{l}\text { Unstandardized } \\
\text { Coefficients }\end{array}$ & & \multicolumn{3}{l}{$\begin{array}{l}\text { Standardized } \\
\text { Coefficients }\end{array}$} \\
\hline & & B & Std. Error & Beta & t & Sig. \\
\hline $\begin{array}{l}\text { Model } \\
1\end{array}$ & $\begin{array}{lllll}\text { (Constant) } \\
\text { Kecerdasan }\end{array}$ & 9,314 & 7,070 & & 1,317 &, 196 \\
& Intelektual & &, 229 &, 544 & 3,993 &, 000 \\
\hline
\end{tabular}

\section{Pembahasan}

Berdasarkan hasil analisis sebelumnya menunjukan bahwa variabel kecerdasan intelektual memiliki pengaruh positif dan signifikan terhadap prestasi belajar siswa. Hasil analisis juga menunjukan besarnya pengaruh kecerdasan intelektual terhadap prestasi belajar yaitu sebesar $29,6 \%$. Hal ini menunjukan bahwa kecerdasan intelektual memiliki kontribusi yang relatif cukup penting untuk dipertimbangkan dalam pembelajaran. Meski sebesar 70,4\% lainnya merupakan pengaruh dari faktor lain di luar kecerdasan intelektual. Sesuai dengan telaah dari beberapa penelitian lainnya yang mengkaji prestasi belajar menunjukkan bahwa kecerdasan intelektual bukan satu-satunya faktor yang memprediksi prestasi seseorang, seperti dalam penelitian Kurnia (2019) bahwa faktor kecerdasan emosional, faktor kecerdasan spiritual pelajar mempunyai pengaruh yang signifikan dalam pencapaikan prestasi pelajar. Hal ini selaras dengan yang disampaikan Goleman (dalam Bestari dan Marhalinda 2017) bahwa kecerdasan intelektual memiliki pengaruh sebesar 20\% terhadap prestasi seseorang, sedangkan sebesar $80 \%$ disebabkan oleh faktor-faktor lainnya.

Hasil penelitian menunjukkan bahwa kecerdasan intelektual mempengaruhi tinggi rendahnya prestasi pelajar siswa. Semakin tinggi kecerdasan intelektual siswa, maka prestasi belajar yang dicapaipun akan semakin tinggi. Demikian juga sebaliknya, semakin rendah kecerdasan intelektual siswa, maka prestasi belajarpun cenderung rendah. Hasil penelitian ini sejalan dengan penelitian yang dilakukan oleh Fitriana, Imron, dan Arif (2016) bahwa kecerdasan intelektual berpengaruh terhadap prestasi belajar. Begitupula hasil penelitian Damayanti (2016) yang juga menunjukan kecerdasan intelektual berpengaruh secara signifikan pada pencapaian prestasi pelajar pada bidang mata pelajaran IPS. Hasil penelitian ini menjelaskan kecerdasan intelektual secara umum dapat diartikan sebagai sebagai suatu kemampuan psiko fisik dalam merespon rangsangan atau perilaku menyesuaikan diri dengan 
lingkungannya dengan cara yang tepat. Dengan demikian, dikatakan bahwa kecerdasan ini tidak hanya terkait dengan kualitas otak namun juga organ-organ tubuh lainnya. Berdasarkan hasil analisis data pada penelitian ini menunjukkan bahwa semakin tinggi kecerdasan seseseorang, semakin besar peluang individu meraih sukses dan berprestasi. Demikian juga sebaliknya bahwa semakin rendah tingkat kecerdasan intelektual seseorang, cenderung kesulitan dalam meneriman dan memproses informasi yang berpengaruh pada capaian prestasi akademiknya (Bungawati, Taiyeb, \& Hartati, 2018).

Kecerdasan intelektual diperlukan untuk mengukur kemampuan seseorang dalam memahami ide atau konsep yang dinyatakan dalam kata-kata, artinya kemampuan merealisasikan dari sesuatu yang abstrak menjadi suatu yang nyata dalam tindakan (Harahap, 2019). Kecerdasan intelektual tidak dapat dipisahkan dengan kemampuan seseorang dalam berkomunikasi secara lisan ataupun bentuk tulisan sehingga menunjukkan bahwa siswa yang memiliki kemampuan tersebut berpeluang untuk berprestasi pada pelajaran-pelajaran di sekolah (Rosa, 2018). Selain itu juga diperkuat dengan temuan Herlina dan Suwatno, (2018) yang menunjukkan hubungan yang sangat signifikan antara kecerdasan intelektual dan hasil belajar siswa. Prestasi hasil belajar siswa berkaitan dengan prestasi belajar kognitif, dimana dalam ranah kognitif menurut Bloom meliputi aktifitas mengingat, memahami, menerapkan, menganalisis, mengevaluasi dan mencipta (Pratama \& Corebina, 2015).

\section{Simpulan}

Hasil dari penelitian ini menunjukkan bahwa variabel kecerdasan intelektual (IQ) memiliki hubungan yang signifikan terhadap prestasi belajar siswa-siswi kelas XI peminatan MIPA SMA Negeri 8 Yogyakarta. IQ dalam penelitian ini menunjukkan kontribusinya dalam membentuk prestasi pelajar sebesar $29,4 \%$ sementara sisanya dipengaruhi oleh faktor lain. Faktor lain yang terkait dengan capaian prestasi belajar siswa belum terungkap dalam penelitian ini seperti peranan kecerdasan emosional, kecerdasan spiritual, dukungan orang tua dan pola atau gaya belajar. Hal ini menjadi satu catatan tersendiri dalam perkembangan dunia pendidikan di Indonesia yang masih dominan dengan menggunakan sistem konvensional terutama untuk sistem seleksi siswa pada sekolah-sekolah negeri. Sistem konvensional yang dimaksud adalah sistem yang menekankan hanya pada faktor kognisi. Sementara potensi siswa dengan kecerdasan-kecerdasan lainnya masih sangat mungkin untuk dapat dikembangkan dan dioptimalkan dengan baik.

\section{DAFTAR PUSTAKA}

Alfionita, A., \& Jamaludin, U., \& Fitrayadi, D.S. (2019). Hubungan antara kecerdasan intelektual (IQ) dengan prestasi belajar siswa pada mata pelajaran Pendidikan Kewarganegaraan. Pro Patria: Jurnal pendidikan, kewarganegaraan, hukum, sosial dan politik, 1 (1), 139-149. DOI: https://doi.org/10.47080/propatria.v2i2.589.

Amaliyah, A. (2017). Hubungan kecerdasan intelektual dan kecerdasan emosional dengan prestasi belajar siswa SD Muhammadiyah 29 Sunggal Deli Serdang. Jurnal ANSIRU, 1 (1), 64-87.

Arikunto, S. (2006). Prosedur penelitian suatu pendekatan praktis. Jakarta: Rineka Cipta.

Azwar, S. (2002). Tes prestasi fungsi dan pengembangan pengukuran prestasi belajar. Yogyakarta: Pustaka Pelajar.

Bestari, R.E., \& Marhalinda. (2017). Kecerdasan intelektual (IQ), kecerdasan emosional (EQ) dan kecerdasan spiritual mempengaruhi kinerja karyawan PT Perusahaan Gas Negara (persero) tbk area Bekasi. https://osf.io/z7kch. 10.31219/osf.io/z7kch. 
Bungawati, B., Taiyeb, A.M., \& Hartati, H. (2018). Pengaruh kecerdasan intelektual, kecerdasan emosional dan kecerdasan spiritual terhadap hasil belajar Biologi siswa SMA Negeri di Kabupaten Soppeng. UNM Journal of biological education, 1 (2), 191-202.

Carter, P. (2009). Tes IQ dan tes kepribadian. Jakarta: PT Indeks.

Damayanti, D. A. (2016). Pengaruh kecerdasan intelektual dan motivasi belajar siswa terhadap prestasi belajar IPS siswa SMK Negeri 1 Gending Kabupaten Probolinggo. Jurnal Penelitian dan Pendidikan IPS (JPPI), 10 (3), 329-336.

Davidoff, L. (2000). Psikologi suatu pengantar. Jakarta: Erlangga.

Depdikbud. (2003). Undang-undang RI NO 20 Tahun 2003 tentang sistem pendidikan nasional. Semarang: Aneka Ilmu.

Dinger, F. C., \& Dickhäuser, O. (2013). Does implicit theory of intelligence cause achievement goals? Evidence from an experimental study. International Journal of Educational Research, 61, 38-47. doi: 10.1016/j.ijer.2013.03.008.

Farida, S. (2016). Pendidikan karakter dalam perspektif Islam. Kabilah: journal of social community, 1 (1), 198-207. http://ejournal.kopertais4.or.id/madura/index.php/ kabilah/article/view/1724.

Fitriana, A., Imron, A., \& Arif, S. (2017). Hubungan antara hasil test IQ (Intelligence Quotient) dengan prestasi belajar siswa. PESAGI: Jurnal Penelitian dan Sejarah.

Goleman, D. (2000). Kecerdasan emosi: Mengapa emotional intelligence lebih tinggi daripada $I Q$, Alih Bahasa: T. Hermay, PT. Gramedia Pustaka Utama, Jakarta.

Handriani, N., \& Subhan, M. (2020). Hubungan kecerdasan intelektual kecerdasan emosional dan kecerdasan spiritual terhadap prestasi belajar fisika. Edu Grafiti: Jurnal Pendidikan Fisika, 3 (1), 1-4. doi: https://doi.org/10.33627/ge.v3i1.

Harahap, E.S. (2019). Pengaruh kebiasaan belajar dan kecerdasan intelektual (IQ) terhadap prestasi belajar siswa pada mata pelajaran ekonomi di kelas X SMA Negeri 7 Padangsidimpuan. Jurnal education and development, 7 (1), 1-7.

Herlina, L., \& Suwatno, S. (2018). Kecerdasan intelektual dan minat belajar sebagai determinan prestasi belajar siswa. Jurnal Pendidikan Manajemen Perkantoran, 3 (2), 246-254. doi: 10.17509/jpm.v3i2.11770.

Imas, B. (2014). Implementasi kurikulum 2013. Jakarta: Kata Pena.

Imron, M., Busnawir, B., \& Samparadja, H. (2016) Pengaruh kecerdasan emosional, kecerdasan spiritual, kecerdasan intelektual dan perilaku belajar terhadap prestasi belajar matematika siswa Madrasah Aliyah. Jurnal Berpikir Pembelajaran Matematika, 1 (2), 19-30. doi: http://dx.doi.org/10.33772/jpbm.v1i2.8145.

Kurnia, H. (2019). Pengaruh kecerdasan intelektual, emosional dan spiritual terhadap prestasi belajar Pendidikan Kewarganegaraan. AoEJ: Academy of eduaction journal, 10 (1), 1-21.

Nurbaeti, N., Nuryanti, S., \& Pursitasari, I.D. (2015). Hubungan gaya belajar dengan keterampilan berpikir kritis dan kemampuan kognitif siswa pada pata pelajaran Kimia di kelas X SMKN 1 Bungku Tengah. Mitra Sains, 3 (2), 24-33.

Nurhayati, A.R., \& Syahrizal, S. (2016). Hubungan kecerdasan intelektual dengan prestasi belajar santri Dayah terpadu Almadinat Uddiniyah Syamsuddhuha Cot Murong Aceh Utara. EDUKASI: Jurnal Penelitian Pendidikan Agama dan Keagamaan, 14 (2), 207-222.

Parauba, I. (2014) Pengaruh kecerdasan intelektual, kecerdasan emosional, kecerdasan spiritual, dan perilaku belajar terhadap pemahaman akuntansi mahasiswa fakultas Ekonomi dan Bisnis Universitas Sam Ratulangi Manado. Going concern, 9 (2), 53-67.

Pratama, A.T., \& Corebima, A.D. (2015) Hubungan intelligence quotient (IQ) terhadap capaian prestasi belajar biologi SMA kota Medan. BIOSEL (Biology Science and Education): Jurnal Penelitian Science dan Pendidikan, 4 (2), 1-12. doi: http://dx.doi.org/10.33477/ bs.v4i2.534. 
Puspatanjali, I.M., Mallo, B., \& Hadjar, I. (2015). Pengaruh intelligence quotient dan emotional quotient terhadap prestasi belajar Matematika siswa kelas X SMA Negeri 1 Sausu. Jurnal Elektronik Pendidikan Matematika Tadulako, 3 (1), 115-122.

Rahardjo, M. (2010, Mei). Antara IQ, EQ dan SQ. Diunduh: https://www.uin-malang.ac.id /w/1416650876/18. 10 Januari 2021.

Rosa, E. (2018). Pengaruh persepsi peserta didik atas gaya belajar dan kecerdasan intelektual terhadap prestasi belajar Bahasa Inggris. INFERENCE: Journal of English Language Teaching, 1 (1), 33-42.

Sudjana, N. (2010). Penilaian hasil proses belajar mengajar. Bandung: PT Remaja.

Sulastyaningrum, R., Martono, T., Wahyono, B. (2019). pengaruh kecerdasan intelektual, kecerdasan emosional, dan kecerdasan spiritual terhadap prestasi belajar mata pelajaran Ekonomi pada peserta didik Kelas XI IPS di SMA Negeri 1 Bulu tahun ajaran 2017/2018. BISE: Jurnal Pendidikan Bisnis dan Ekonomi, 4 (2), 1-18.

Suryabrata, S. (2006). Psikologi pendidikan, Jakarta: T. Raja Grafindo Persada.

Zuffianò, A., Alessandri, G., Gerbino, M., Luengo Kanacri, B. P., Di Giunta, L., Milioni, M., \& Caprara, G. V. (2013). Academic achievement: The unique contribution of self-efficacy beliefs in self-regulated learning beyond intelligence, personality traits, and selfesteem. Learning and Individual Differences, 23, 158-162. doi: 10.1016/j.lindif. 2012.07.010. 